\title{
MEDICAL AND PSYCHOLOGICAL ASPECTS OF SAFETY AND ADAPTATION OF MILITARY PERSONNEL TO EXTREME CONDITIONS
}

DOI: 10.36740/WLek202004110

\author{
Ihor I. Prykhodko', Serhii V. Bielai' , Anatolii M. Hrynzovskyi' ${ }^{2}$ Anatolii M. Zhelaho' ${ }^{1}$, Serhii 0. Hodlevskyi ${ }^{1}$, \\ Svitlana I. Kalashchenko² \\ 'NATIONAL ACADEMY OF THE NATIONAL GUARD OF UKRAINE, KHARKIV, UKRAINE \\ 2BOGOMOLETS NATIONAL MEDICAL UNIVERSITY, KYIV, UKRAINE
}

\begin{abstract}
The aim: To determine the dynamics of adaptation resources and the level of psychological safety of the personality in service members of the National Guard of Ukraine who participated in combat operations in the East of Ukraine.

Materials and methods: To determine the peculiarities of military personnel adaptation to the combat activity, the "Adaptability-200" and "Disdaptability-45" methodologies were used. To determine the level of psychological safety of combatants we used "Diagnosis of psychological safety personality" and "Express diagnosis of psychological safety personality" Methodologies. The study was carried out during 2017, with 163 military participating.

Results: Being 2-3 weeks in combat conditions, $54 \%$ service members revealed high, $32 \%$ - average level of adaptability, and in $14 \%$ of them signs of non-adaptability were detected. The data of adaptation resources of combatants correlates with the results of diagnostics of psychological safety of personality: in $43 \%$ of them high level, $42 \%$ average and $15 \%$ - low level of psychological safety were revealed.

Conclusions: The data obtained in the absolute majority of service members (86\%) shows a good adaptability to combat conditions, and allows predicting adequate response to extreme conditions, high probability of preserving of the mental health and disability after the influence of vital factors.
\end{abstract}

KEY WORDS: adaptation, psychological safety, service members, extreme conditions

\section{INTRODUCTION}

The problem of predicting human behavior in extreme conditions of activity, as well as the assessment of the probability of maintaining their mental health and ability to work after the influence of vital factors, has always been the focus of attention of scientists, practical psychologists and psychiatrists. Local armed conflicts occupy a special place among extreme situations, which include the hostilities that have taken place in eastern Ukraine since 2014. One of the main aspects of this issue is maintaining the personal (physical and psychological) safety of the military, as well as their successful adaptation to the stressful conditions of warfare. The medical and psychological consequences of the influence of destructive factors on the mentality of a serviceman during the conduct of hostilities and after their completion determine a wide range of various psychogenic disorders, which various authors describe as martial psychological trauma, combat fatigue, combat stress, social stress disorder, combatant accentuation of an individual, combat psychological traumatism, post-traumatic stress disorder (PTSD), etc. Psychogenic disorders, when the ability for self-regulation of the psychophysiological states in the military is underdeveloped can lead to the development and increase in the number of diseases of different etiologies, especially psychosomatic ones, which in the future deteriorates personnel perfomance.

There are many studies related to the definition of the effects of combat conditions and their influence on the physical and mental state of military personnel and veterans of combat operations. Escolas, Pitts, Safer, Bartone studied the protective value of hardiness in post-traumatic stress [1]. The authors examined the protective effects of hardiness (dispositional resilience) in self-reported PTSD symptoms in a sample of post-deployed service members. They proved that the severity was negatively related to PTSD symptoms. Time in the military, number of deployments, and total time spent on deployment were positively related to PTSD symptoms. Hardiness moderated the effects of time in the military on PTSD symptoms, such that time in military had no effect on those who were high in hardiness. Hardiness did not moderate the effects of either deployment measure.

Schreiber, McEnany to explore the impact of stigma on American military personnel with psychiatric illness [2]. They concluded that after the end of hostilities, most survivors do not seek or receive mental health care and stigma is one of the main barriers to that care.

Overstreet, Brown, Berenz et al. studied the relationship between PTSD and anxiety sensitivity (AS) and distress 
tolerance (DT) typologies of veterans [3]. Results indicated a 3-cluster solution including a high AS / low DT "at risk" profile, a low AS / high DT "resilient" profile, and an average AS / DT "intermediate" profile. The at-risk profile was associated with significantly higher symptoms in each PTSD cluster (i.e., hyperactivity, avoidance, re-experiencing) when compared to the other two profiles. The at-risk profile was also associated with greater depressive symptoms and lower self-reported resilience.

Paige, Renshaw, Allen et al. studied deployment trauma and seeking treatment for PTSD in US soldiers [4]. The authors found that there are four types of potentially traumatizing warzone experiences: committing a moral injury, observing a moral injury, threats to life, and traumatic loss.

Griffith made research of the relationships of deployment and combat experiences to postdeployment negative health conditions among Army National Guard soldiers [5]. Author's attention has been paid to non-clinical conditions, which have posed significant adjunctive problems for soldiers, in particular for reserve soldiers who return to civilian life, family and employment. Griffith J. Reliably indicated seven problem areas. The highest prevalence of problems was being angry (35.9\%) and being unable to sleep (43.3\%), followed by alcohol abuse (25.1\%). Longer deployment lengths were associated with troubled relationships and aggression towards other significant adults and children in the household. More deployments were associated with aggression towards householder children. Self-reported general combat trauma and having killed or wounded someone were associated with all problem areas.

Novikov, Bochenkov, Chermyanin conducted a study of the psychophysiological state of military personnel before the beginning of hostilities in Chechnya (Russian Federation) and at the first stage of the conflict (1994-1995) [6]. The authors proved that only $28 \%$ of the personnel were relatively healthy, $72 \%$ had asthenic-depressive $(46 \%)$ or psychotic (26\%) reactions requiring operative psychophysiological and pharmacological correction. They noted that almost all surveyed patients had symptoms of asthenia with various neuro-psychic disorders, neuro-psychic instability increased from $22 \%$ at the beginning to $38 \%$ after $21-49$ days of hostilities. In $52 \%$, a satisfactory level of psychophysiological combat ability of personnel was determined, and in $48 \%$ - unsatisfactory: due to the prolonged locating in the combat zone, the general condition deteriorated, situational anxiety increased, signs of isteroid accentuation of the person (impulsivity, demonstrativity) appeared.

Similar data was confirmed by the results of modern Ukrainian studies on the effect of combat stress on service members and their social and psychological adaptation upon returning from the combat zone. Druz indicates that about $80 \%$ of military personnel, who participated in hostilities during the anti-terrorist operation (ATO) in the East of Ukraine, received combat stress, which was subsequently transformed into approximately $25 \%$ of PTSD of varying degrees of severity [7]. The author indicates that $98 \%$ of combatants need qualified psychological support and assistance because of combat stress factors, $20 \%$ have subthreshold signs of PTSD (disadaptative reactions), and $27 \%$ have incomplete clinical manifestations of PTSD, which lead to daily adverse effects. Seventy five percent of combatants hid their psychological problems and never received adequate help. At the same time, $93 \%$ of the military were shy or prevented the detection of mental problems [8].

Non-adaptability processes under the influence of extreme conditions affects not only the mental health of the military, but also their physical status. First, it can lead to an increased blood pressure, heart rate, a significant loss in body weight and an increase in cases of acute respiratory illness.

At the beginning of the ATO, after the return of National Guard of Ukraine (NGU) personnel from the combat zone to the home barracks, Prykhodko, Kolesnichenko, Matsegora et al (2014) found a low level of social and personal adaptation for the conditions of combat operations in $25 \%$ of officers, $33 \%$ of contracted service members and $22 \%$ of the mandatory service soldiers [8]. This, according to the authors, was associated with the low level of professional training of the military mobilized from the reserve, and with the lack of professional psychological selection for determining suitability for military service of the main part of them.

In many studies, the authors considered a variety of aspects of this complex and at the same time very important problem. The definition of the dynamics of adaptation processes, for example, of service members who took part in hostilities in the East of Ukraine, will expand and supplement the conception of preserving the physical and psychological security of the individual in extreme conditions.

\section{THE AIM}

The aim of the study was to determine the dynamics of adaptive resources and the level of psychological safety of personality (PSP) of the NGU military personnel, who participated in combat operations in the East of Ukraine. Research hypothesis: Extreme conditions adversely affect the psyche of the military participating in hostilities and is a threat to their personal safety.

\section{MATERIALS AND METHODS}

The methodology of the multi-level personal questionnaire "Adaptability" (Maklakov, 1994) [9] and its modification "Adaptivity-200" (Chermyanin, Kondratyev) were created to determine the features of the adaptation of service members to extreme (combat) conditions. Methodology "Adaptability" consists of 165 statements, which are united into four scales, the integral indicator (personal adaptation potential) is calculated as the sum of points by the scale "Behavioral regulation", "Communicative Potential", "Moral Normativity" (the scale "Sincerity" was not considered). While retaining the main scales of the "Adaptability" methodology, the "Adaptivity-200" methodology was later developed, which was supplemented by 35 statements (in total 200 of 
them), and the following three scales were identified: "Military-professional Orientation", "Aptitude to Deviant Forms of Behavior", "Suicidal Risk", and, as an integral indicator, the level of resistance to combat stress was calculated.

The methodology "Disadaptability-45" (Prykhodko, Kolesnichenko, Matsegora, Bayda, 2017) is a shortened version of the "Adaptability-200", consisting of 45 statements, which are included into five scales [10]. The level of non-adaptability was calculated as the sum of points by the scales "Violations of Behavioral Regulation", "Loss of Communicative Potential", "Violation of Moral Normality" and "Probability of Committing Suicidal Attempts" (the scale "Sincerity" was not considered). Appropriate validation, standardization and practical testing in the combat zone have followed the methodology.

Methodology "Diagnosis of Psychological Safety of a Person" (DPSP-88) of a specialist of an extreme type of activity (Prykhodko, 2012) was designed to determine the psychological safety of personality, which reflects the ability of the human psyche to resist dangers and create safe conditions for life [11]. DPSP-88 consisted of 88 statements, which were included into four scales "Moral-Communicative", "Motivational-Volitional", "Value-Sense", "Internal Comfort". As an integral indicator, the level of PSP was calculated as the sum of four scales. To use the methodology in extreme conditions, its shortened version - "Express Diagnostics of Psychological Safety of a Person" (EDPSP-28) - has been developed, consisted of 28 statements, which were included into four scales: "Moral and Volitional Regulation", "Strategies for Overcoming Stressful Situations", "Value-Sense", "Posttraumatic Growth / Regression". As an integral indicator, the PSP level was calculated as the sum of four scales.

The survey was conducted during 2017, with 163 NGU service members participating in it. All the surveyed were professional contracted military, who, before being sent to the combat zone, received professional and psychological training, they were pre-selected to perform missions in extreme conditions using the "Adaptivity-200" and DPSP-88 methodologies.

Ethics approval and consent to participate: All procedures performed in studies involving human participants were in accordance with the ethical standards of the National Scientific Center for Medical and Biotechnical Research of the NAS of Ukraine, based on the Helsinki Declaration of 1964 and its subsequent amendments. Permission for research received in the Research Committee of virtue and ethics National Academy of the National Guard of Ukraine. Informed consent was sought from all the participants.

\section{RESULTS AND DISCUSSION}

Before sending to the combat zone, the psychodiagnosis of all NGU personnel was conducted in order to determine the resources and levels of psychological safety of personality. To do this, the methods "Adaptivity-200" and DSPO- 88 were used. All troops showed a high, good and satisfactory level of personal adaptation potential, as well as a high and average level of PSP. After that, the military were sent to the combat zone.
During the first two or three weeks of the deployment of personnel in the combat area, psychodiagnosis of service members was re-conducted to study the features and the state of adaptation of the personnel to the conditions of operational and combat activities (OCA) in the zone of ATO. Due to the complexity of conducting the survey in such conditions, the express method "Disadaptivity-45" was used, based on which 77 people were surveyed. The high level of non-adaptability to combat conditions was found in 11 military (14\%), the average in 25 (32\%), low (that is, high level of adaptability) - in 42 (54\%).

For the correlation of the received data of adaptive abilities of military personnel and in order to assess their current mental status, psychodiagnosis of 86 service members was carried out using the EDPSP-28 methodology. The obtained results showed that the high level of psychological safety of personality was detected in 37 military (43\%), the average - in $36(42 \%)$, low - in 13 (15\%).

Describing $54 \%$ of military personnel with a high level of adaptive abilities, it should be noted that they were easy to adapt to new conditions, quickly "entered" into a new team, were easily and adequately guided in difficult situations, and quickly developed a strategy of their behavior and socialization. As a rule, they were non-conflicting, had high resilience. The mental status of this group during the adaptation period remained within the normal limits, and the ability to work was maintained at a sufficient level necessary for the qualitative execution of tasks in combat conditions. Thirty two percent of the group with average level of non-adaptability had signs of different accentuations, which in the usual conditions were partially compensated and might be manifested in the change of activity. These individuals, as a rule, had low resilience, the process of socialization was complicated, therefore, asocial failures, manifestations of aggressiveness and conflict were possible in them. The mental state at the initial stage of adaptation might be violated; therefore, the individuals of this group required control from the junior commanders.

Thus, the absolute majority of service members (86\%) adapted well and satisfactorily to the conditions for performing the OCM in the ATO area.

In $14 \%$ of the military was found a high level of non-adaptability, they had signs of explicit accentuation of character and some signs of psychopathy: their mental state can be described as the ultimate. Individuals of this group had low resilience, were conflicting, can tolerate deviant behavior and delinquent acts. The process of adaptation was hard; they might have possible neuro-psychic failures, negative psychic reactions, signs of a long violation of the mental condition, sleep disorders which led to malfunctioning of the cardiovascular and nervous systems. The data obtained correlated with the results of studies of Hughes, Ulmer, Hastings et al. (2018), which determined that veterans' poor sleep was associated with a greater psychological distress controlling for health [12]. Both resilience factors have adapted and self-efficacy - have had significant buffering effects on the relationship between poor sleep and psychological distress, suggesting that resilience can protect against negative outcomes in poor sleepers. Combatants' inadequate response to extreme conditions using negative coping behaviors may 
be predictors of the development and maintenance of PTSD. This was also confirmed by Sheerin, Chowdhury, Lind et al. (2018) who found that avoiding coping, but no other coping strategy, was significantly positively related to PTSD diagnosis in the initial step [13].

Therefore, these service members with signs of violation of adaptation to extreme conditions required constant control by the unit's commanders, deputy commanders for personnel as well as by the junior commanders. The individualized casework activities and monitoring were constantly carried out to them.

The psychological safety of a service member personality is an integrative indicator that reflects the mechanism of psychological protection of personality, ability to maintain an optimal level of functioning, the possibility to eliminate the external and internal threats that arise, and to maintain the ability to perform operational and combat missions in ordinary and extreme conditions at a sufficiently stable level [14]. To provide PSP under normal conditions, the potential of four components was used: Moral-Communicative, Motivational-Volitional, Value-Sense, and Internal Comfort. In extreme conditions, the PSP transforms creating four other components: Moral and Voluntary Regulation, Strategies for Overcoming Stressful Situations, the Value-Sense component and Posttraumatic Growth / Regression.

The high level of PSP characterizes individuals as psychologically protected, resistant to external and internal hazards. The levels of unstable (limitary) PSP represent the possibility of transition to the first or second state under the influence of external or internal factors. The low level of psychological protection of personality or the lack of psychological safety indicates a high probability of mental disorders, a tendency to failures in the functioning of the individual, which may appear in behavioral disorders and activities. A good example of such malfunctioning can be the emergence of physical exhaustion, trembling, shuddering for any sound or movement, increased sweating.

As outcome of the study of the dynamics of PSP the following data has been received. In $43 \%$ of the military a high level of PSP was detected, indicating their responsibility for their relationships and the trust in their loved ones, the ability to establish and maintain close relationships, tolerance in interpersonal relationships, knowledge and use of social norms to maintain the necessary comfortable relationships, and flexible control of relationships with others: perceiving them as they are. These service members, as a rule, have developed volitional qualities: willpower, purposefulness, endurance. They had a good ability to active life planning, strong motivation for the achievements, inner locus of control (internality), high initiative, autonomy and independence of thinking, aptness to innovate and to take justifiable risk, resilience. They had an understanding of their own lives, the ability for comprehended regulation of activities: are involved in the life of social environment, personally responsible, able to rise above the situation, were characterized by active overcoming of difficulties, usage of productive coping-strategies to overcome stress situations. They were self-confident, assured in their own attractiveness for others, showed satisfaction with their lives and their relationships, strived for a high quality of life and had a low anxiety.
Describing $42 \%$ of personnel in which the averagelevel of PSP was detected, we note that for such persons there were certain limitations in the relationships and trust of close people that might cause some discomfort in communication. They had inadequate knowledge and were characterized by the limited use of social norms to maintain the necessary comfortable relationships. These service members had limited volitional qualities and innovative abilities, indicating certain experiences regarding their own independence, initiative and independence of thinking. They might have difficulty in life planning as well as insufficient control over their own lives. In addition, there were some issues in determining their own sense of life, comprehended regulation of activities, as well as reduced overall activity; there was a moderate dependence on certain situations and circumstances. Overcoming difficulties could be difficult and slow; military did not always choose productive strategies to overcome stressful situations, might have moderate anxiety, malaise, doubts about self-confidence, initial manifestations of asthenic reactions.

For $15 \%$ of personnel with low levels of PSP, dependence on others or fear of being dependent on them and, as a consequence, the desire for isolation, separation, loneliness were characteristic. The inability of establishing and maintaining relations were manifested, the avoidance of close relations was observed, as well as the dependence on the rules regulating social relations. They were characterized by weakness, disorganization, instability to life's difficulties; the main motivation was to avoid failures, externality. Such military showed passivity; dependence in decision-making, and low control of his (her) life were noted. They showed high anxiety, uncertainty in themselves; there were internally unpleasant sensations (phenomena of asthenic reactions, hypochondria).

Thus, a survey of 153 ATO military personnel showed that the absolute majority of the personnel (86\%) was well adapted to the extreme conditions when carrying out missions in the ATO zone. The revealed high and average level of development of PSP in $85 \%$ of the surveyed showed that they were capable of performing combat missions without significant damage to their psyche.

The military, in which a high level of non-adaptability and the low level of PSP were detected, were transferred to the support unit and further examined by a psychiatrist for determining the signs of mental disorders. Disorders of the psyche according to the ICD-10 were not identified, for those service members additional psychoprophylaxis was carried out.

\section{CONCLUSIONS}

1 . The data obtained in the absolute majority of the military (86\%) allows us to speak about good adaptability to combat conditions, and to predict adequate response to extreme conditions, high probability of preserving the mental health and ability to work after the influence of the vital factors.

2. Service members, in which high non-adaptability and low level of PSPs were revealed, require the obligatory transfer to the support units and implementation of additional psychoprophylaxis activities. 
3. Failure to perform psychological help during an increase in the intensity of combat operations can lead to the growth in short-term and long-term psychogenic losses (a forecast of 14 to 26\% and more), the emergence of psychogenically caused mental disorders in personnel and the subsequent possibility of development of PTSD.

\section{REFERENCES}

1. Escolas S.M., Pitts B.L., Safer M.A. et al. The Protective Value of Hardiness on Military Posttraumatic Stress Symptoms. Military Psychology. 2013; 25(2):116-123. doi.org/10.1037/h0094953.

2. Schreiber M., McEnany G.P. Stigma, American military personnel and mental health care: challenges from Iraq and Afghanistan. Journal of Mental Health. 2015; 24(1):54-59. doi.org/10.3109/09638237.2014. 971147.

3. OverstreetC., Brown E., Berenz E.C. et al. Anxiety sensitivity and distress tolerance typologies and relations to posttraumatic stress disorder: A cluster analytic approach. Military Psychology. 2018; 30(6):547-556. doi.org/10.1080/08995605.2018.1521682.

4. Paige L., Renshaw K.D., Allen E.S. et al. Deployment trauma and seeking treatment for PTSD in US soldiers. Military Psychology. 2019; 31(1):26-34. doi.org/10.1080/08995605.2018.1525219.

5. Griffith J. Relationships of deployment and combat experiences to postdeployment negative health conditions among Army National Guard soldiers. Military Psychology. 2019; 31(2):128-137. doi.org/10. 1080/08995605.2019.1565908.

6. Novikov V.S., Bochenkov A.A., Chermyanin S.V. Psihofiziologicheskoe obosnovanie problemyi korrektsii i reabilitatsii uchastvovavshih $\mathrm{v}$ boevoy deyatelnosti voennosluzhaschih [Psychophysiological substantiation of the problem of correction and rehabilitation of military personnel who participated in combat activities] Military Medical Journal. 1997; 3:53-57. (In Russian)

7. Druz 0.V. Donbasskiy sindrom: $93 \%$ uchastnikov AT0 opasnyi dlya sebya i obschestva [Donbass syndrome: $93 \%$ of ATO participants are dangerous for themselves and society]. Psykholohichna reabilitatsiia ta psykhiatrychna dopomoha uchasnykiv antyterorystychnoi operatsii. Shliakhy zmenshennia suitsydiv sered viiskovosluzhbovtsiv ta demobilizovanykh iz zony ATO: zasidannia komitetu z okhorony zdorovia Verkhovnoi Rady Ukrainy. August 25, 2017. https://inforesist. org/glavnyiy-psihiatr-minoboronyi-93-atoshnikov-potentsialnayaugroza-dlya-obshhestva. (In Russian)

8. Prykhodko I.I., Kolesnichenko 0.S., Matsehora Ya.V. et al. Psykholohichnyi suprovid sluzhbovo-boiovoi diialnosti viiskovosluzhbovtsiv Natsionalnoi hvardii Ukrainy v ekstremalnykh umovakh [Psychological support of military-military activity of servicemen of the National Guard of Ukraine in extreme conditions]. Honor and law. 2014; 3:68-74. (In Ukrainian)

9. Maklakov A.G. Mnogourovnevyiy lichnostnyiy oprosnik «Adaptivnost» [Multi-level personal questionnaire"Adaptability"]. In: Professionalnyiy psihologicheskiy otbor kandidatov v voenno-uchebnyie zavedeniya Ministerstva oboronyi Rossiyskoy Federatsii [Professional psychological selection of candidates for military schools of the Ministry of Defense of the Russian Federation]. Moscow; 1994, p. 164-174. (In Russian)

10. Prykhodko I..., Matsehora Ya.V., Kolesnichenko 0.S. et al. Ekspresopytuvalnyk «Dezadaptyvnist»: rozroblennia, aprobatsiia, psykhometrychni pokaznyky [Express-opitvuvalnik "Disadaptive": production, testing, psychometric shows]. Bulletin of the National Academy of State Derivatives Service of Ukraine. 2017; 3. http://nbuv. gov.ua/UJRN/Vnadpn_2017_3_8. (In Ukrainian)
11. Prykhodko I.I. Rozrobka psykhodiahnostychnoho instrumentariiu vyznachennia psykholohichnoi bezpeky osobystosti fakhivtsiv ekstremalnykh vydiv diialnosti [Development of psychodiagnostic tools for determining the psychological safety of the personality of specialists in extreme activities]. Scientific Bulletin of Lviv State University of Internal Affairs. 2012; 2(1):312-322. (In Ukrainian)

12. Hughes J.M., Ulmer C.S., Hastings S.N. et al. Sleep, resilience, and psychological distress in United States military Veterans. Military Psychology. 2018; 30(5):404-414. doi.org/10.1080/08995605.2018. 1478551.

13. Sheerin C.M., Chowdhury N., Lind M.J. et al. Relation between coping and posttrauma cognitions on PTSD in a combat-trauma population. Military Psychology. 2018; 30(2):98-107. doi.org/10.1080/08995605. 2017.1420980.

14. Prykhodko I.I. Psykholohichna bezpeka personalu ekstremalnykh vydiv diialnosti: kontseptsiia, transformatsiina model, metodolohiia doslidzhennia [Psychological security of the personnel of extreme types of activity: concept, transformational model, research methodology]. Actual problems of sociology, psychology, pedagogy. 2015; 4(29):117125. (In Ukrainian)

The article was completed in the framework of the research project "Development of a program for the prevention of post-traumatic stress disorder in the military personnel of the National Guard of Ukraine participating in hostilities" (the code "Stress") (state registration № 0218U006866), which was carried out in 2016-2017 in the Research Center of the National Academy of the National Guard of Ukraine.

\section{ORCID and contributionship:}

Ihor I. Prykhodko - 0000-0002-4484-9781 A,B,D,E,F

Serhii V. Bielai - 0000-0002-0841-9522 ${ }^{C, D}$

Anatolii M. Hrynzovskyi - 0000-0002-8391-5294 A,E,F

Anatolii M. Zhelaho - 0000-0003-3319-6620 ${ }^{B}$

Serhii O. Hodlevskyi - 0000-0002-0437-7847 ${ }^{B, D}$

Svitlana I. Kalashchenko - 0000-0002-9942-7607 A,C,D,E

\section{Conflicts of interest:}

Authors declare no conflict of interest.

\section{CORRESPONDING AUTHOR Ihor I. Prykhodko}

National Academy of the National Guard of Ukraine sq. Zachisnikiv Ukraine, 3, Kharkiv, 61001, Ukraine e-mail: prikhodko1966@ukr.net

Received: 11.06 .2019

Accepted: 17.02 .2020

A - Work concept and design, B - Data collection and analysis, C - Responsibility for statistical analysis, D-Writing the article, $\mathbf{E}$ - Critical review, $\mathbf{F}$ - Final approval of the article 